学会賞受賞論文

\title{
妊娠高血圧腎症胎盤におけるオートファジーと凝集蛋白蓄積 The role of autophagy for protein aggregation in preeclampsia
}

中島彰俊 a)、草開 妙 a)、青木 藍子 a)、島 友子 a)、鮫島 梓 a)、米田 哲 a)、 Shi-Bin Cheng a)、吉野 修 b)、伊川 正人 c)、吉森 保 d)、Surendra Sharma b)、 齋藤 滋 $\mathrm{a}$

Akitoshi Nakashima a), Tae Kusabiraki a), Aiko Aoki a), Tomoko Shima a), Azusa Sameshima a), Satoshi Yoneda a), Shi-Bin Cheng b), Osamu Yoshino a), Masahito Ikawa c), Tamotsu Yoshimori d), Surendra Sharma b), Shigeru Saito a)

a) 富山大学医学部産科婦人科学教室

Department of Obstetrics and Gynecology, Faculty of Medicine, University of Toyama 干930-0194 富山県富山市杉谷 2630

b) Department of Pediatrics, Women \& Infants hospital, Brown University Department of Pediatrics, Women \& Infants hospital, Brown University Providence, RI, USA

c) 大阪大学 微生物病研究所 遺伝子機能解析分野

Research Institute for Microbial Diseases, Osaka University 干565-0871 大阪府吹田市山田丘 3-1

d) 大阪大学大学院 分子生物学講座 遺伝学教室

Department of Genetics, Graduate School of Medicine, Osaka University

=565-0871 大阪府吹田市山田丘 2-2

キーワード:

オートファジー、妊娠高血圧症候群、凝集蛋白蓄積、絨毛外栄養膜細胞、神経变性疾患

\section{Correspondence:}

Akitoshi Nakashima

Department of Obstetrics and Gynecology, Faculty of Medicine, University of Toyama

Sugitani 2630, Toyama, 930-0194, Japan

Tel: 076-434-7357

Fax: 076-434-5036

E-mail: akinaka@med.u-toyama.ac.jp

\section{要 旨}

妊娠高血圧腎症（Preeclampsia, 以下 PE）は Placenta-mediated pregnancy complications（胎盤関連妊 娠合併症）の一つであり、その他に子宮内胎児発育遅延（Fetal growth restriction、以下 FGR）、死産、 常位胎盤早期剝離などが含まれる。つまり、重篤な周産期合併症の多くは胎盤形成と密接に関係している ことを意味している。これまで、PEの病態形成として 2 ステップセオリーが提唱され、第一ステップと しての胎盤形成不全、第二ステップとしての血管内皮障害が起こるとされてきた ${ }^{[1]}$ これれで我々は、細 胞自身がもつオートファジー（自食作用）という機構に注目し、EVT 機能（浸潤および血管リモデリング） 
抑制がオートファジー抑制に関与することを明らかにしてきた ${ }^{[2]}$ 。らに、近年、胎盤特異的 Atg7 欠損 マウスを作成し、そのマウスでは胎盤形成不全及び母獣血圧の上昇を認めることも報告した ${ }^{[3]}$ 。一方で同 マウスは、蛋白尿および胎児発育不全を合併しないことも明らかとなった。つまり、胎盤におけるオート ファジー抑制は PE の第一ステップと強く関与し、第二ステップには寄与しないことも分かってきた。加 えて、神経変性疾患にみられる凝集蛋白蓄積は、オートファジー抑制を介して PE 胎盤の病態形成にも関 与することが示唆されている。そこで、PEにおけるオートファジーと凝集蛋白蓄積について、本編で概 説する。

\section{1. 緒言}

妊娠高血圧腎症（PE）は、母体及び胎児の生 命を脅かす重篤な妊娠合併症であるが、現在のと ころ分娩のみが有効な治療手段である。PE は “学 説の疾患” と言われるほど、さまざまな仮説が提 唱されているが、その中でも 2 段階仮説が中心 であろう ${ }^{[1]}$ 。その仮説では、第一段階において胎 盤低形成が起こり、第二段階において抗血管新生 阻害因子の増加により、全身性の内皮傷害が起こ り、その結果、胎盤機能低下・母体血圧上昇・蛋 白尿などが発現し、胎児発育不全（fetal growth restriction 以下 FGR）などが出現する、と考えら れている。ここに炎症やホルモンに関連した液性 因子を含む制御が関与し、病態悪化に関わる。 抗血管新生阻害因子とは、可溶型 Flt-1（soluble
Fms-like tyrosine kinase-1 以下 sFlt1) および可溶 型エンドグリン（soluble Endoglin 以下 sEng）で あり、それら抗血管新生阻害因子投与によりマウ スやラットに PE 様症状を誘導できることが知ら れている ${ }^{[4,5]}$ 。また、PEに進展していく妊婦では sFlt1 および sEng が PE 発症前に上昇することも 分かっている ${ }^{[6]}$ 。これら因子の除去は、重症 PE 妊婦の症状を軽減し、妊娠期間を延長することが 分かっているが、未だ実臨床への応用はされてい ない ${ }^{[7]}$ 。そこで、現在は PE 発症を予知し、その 進展を阻害する予防医学的見地からのアスピリン 内服治療がなされ、有効性が報告されている ${ }^{[8]}$ 。 その有効性は、アジア地域の国々での国際試験で も検証されている。

本総説において、オートファジーのメカニズム を解説するとともに、これまで第一段階の原因と

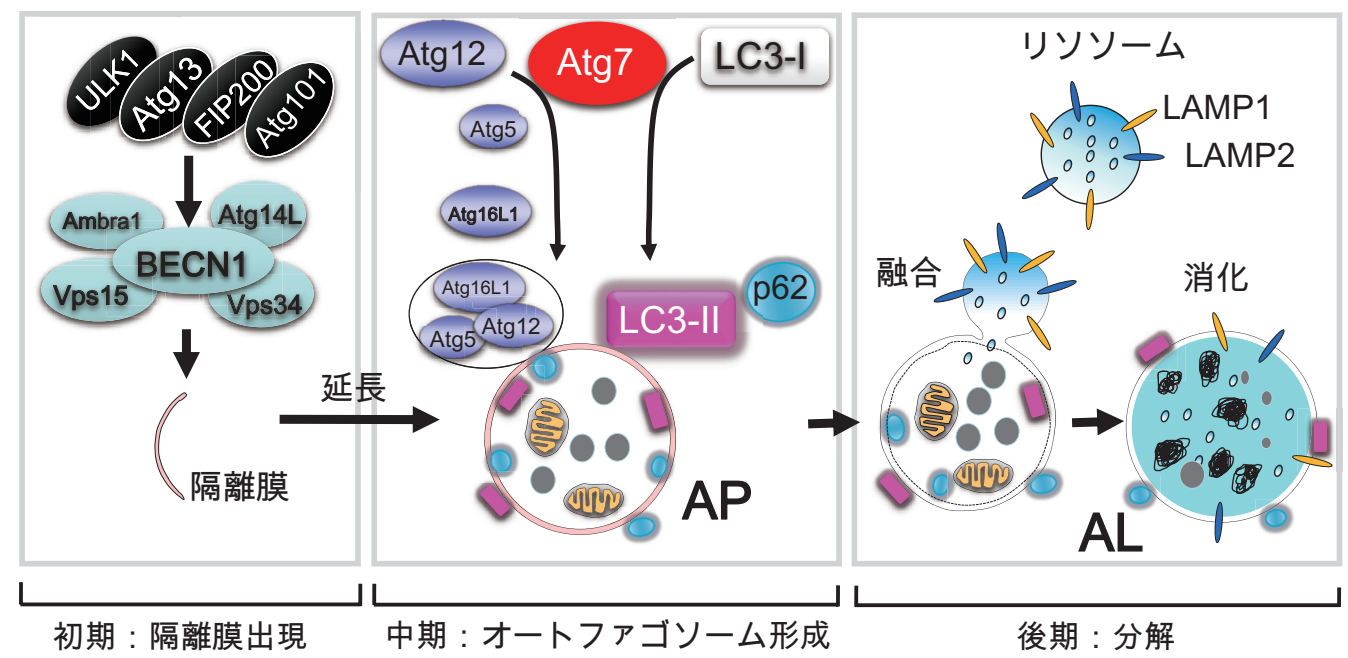

図 1. オートファジーの分子メカニズム

オートファジーの進行は、3つのステップに分かれている。飢餓・低酸素などのストレスが、Beclin-1（BCLN1）などのイニシエーターを活性 化し、細胞質内に隔離二重膜が出現する（初期）。隔離膜には、LC3-IIや p62 がリクルートされ、Atg5-Atg12-Atg16L1 の複合体により膜が伸 長され、最終的に 2 重膜が融合し、オートファゴソーム（AP）となる。LC3 の活性化（phosphatidyl ethanolamine 付加）やAtg5-Atg12Atg16L1 複合体形成に Atg7 は必須の因子である。その後 AP にリソソームが融合し、オートリソソーム (AL) が形成される。 
表 1.オートファジー関連蛋白ノックアゥトマウスの胎児表現型

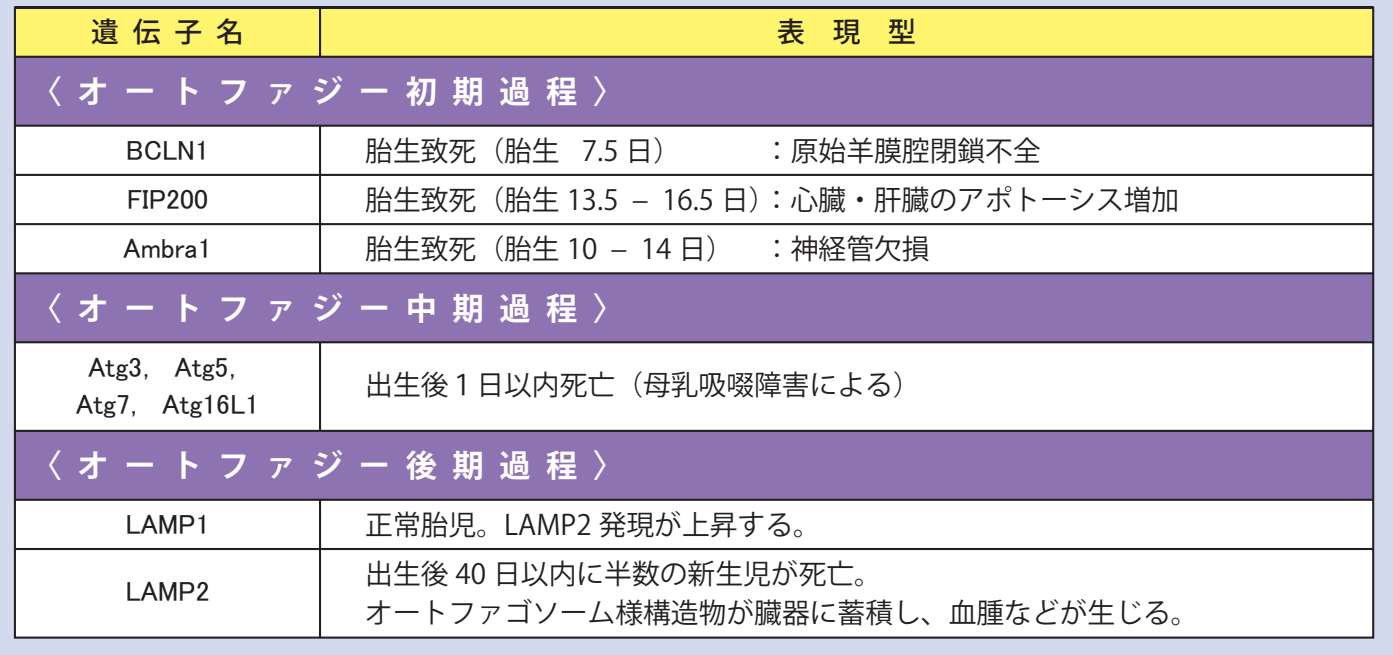

して、免疫系異常・低酸素・酸化ストレス等が提 唱されてきたが、その一つにオートファジー不全 が関与することを紹介する。また、ヒト PE 胎盤 におけるオートファジーの役割を検討する中で、 神経変性疾患等にみられる凝集蛋白蓄積がオート ファジー抑制によって PE 胎盤でも起こりうるこ とも提唱する。

\section{2. オートファジーの分子機構と ノックアゥトマウスの表現型}

オートファジー (Autophagy) は、自己（Auto） を食べる（phage う phagy）という意味であり、 プロテアソーム系と並ぶ細胞内蛋白分解機能のひ とつである。また、オートファジーは東京工業大 学大隅良典栄誉教授によって解明された細胞内機 構で、その研究成果により 2016 年ノーベル生理 学・医学賞を受賞されたことも記憶に新しい。 細胞を構成するタンパク質などの高分子は、一定 期間後細胞によって能動的に分解されており、合 成と分解のバランスによって生命は維持されてい る。その中で、プロテアソーム系は短寿命タンパ ク質の選択的分解を担い、オートファジーは細胞 構成成分など多くの長寿命タンパク質を非選択的 に分解する機構として存在する普遍的な機構であ る。図 1 に示すように、飢餓や低酸素等の刺激が

細胞に加わると、細胞質内に隔離膜が出現し、湾 曲・伸長しながらミトコンドリアやペルキシソー ム等のオルガネラを包み込む。隔離膜の未端同士 が融合し直径約 $1 \mu \mathrm{m}$ の 2 重膜構造が完成し、そ れをオートファゴソームと呼ぶ。その後リソソー ムと融合することでオートリソソームとなり内 容物を消化することで、タンパクを除去する ${ }^{[9]}$ 。 オートファジーは、主に細胞飢餓によって活性化 されるエネルギー産生機構および、細胞内のタン パク品質管理という2 面性をもつことも知られ ている。それ以外にも、リソソーム膜の陥入に よって細胞質内物質を取り込むミクロオートファ ジー（これに比し、通常のオートファジーはマク ロオートファジーと呼ばれる）や、特定のモチー フを持つタンパクをHsc70 および LAMP2A を介 してリソソームに取り込むシャペロン介在性オー トファジーなどがある。

オートファジーは発生・分化、発癌抑制、抗原 提示、免疫応答、病原体排除、炎症反応抑制、心 不全抑制、糖尿病抑制、プログラム細胞死など多 彩な機能を有するが、その機構は大きく分けて、 先に述べたように 3 つステップに分かれる（図 1 )。各ステップに関与する因子を一部記載し た。それらのノックアウトマウスの表現型は各ス テップにおいて特徴があり、初期ステップの欠損 は重篤な表現型を示す傾向にある（表 1 ）[10]。 これには 2 つ原因があると考えられ、1）後期 
ステップ程、他の因子が久損因子を相補するとす る可能性と、2）上流因子であるほどオートファ ジー経路以外への影響が出るため、と推測されて いる。他にもオートファジーと生殖への影響とし て、卵巣特異的 BCLN1 欠損によって、卵巣にお けるプロゲステロン産生の低下により早産が引き 起こされること[11]、オートファジー隔離膜の伸 長に必須因子 Atg5 を受精卵においてノックアウ トすると、胚盤胞への到達率が低下することも分 かっており [12]、オートファジーはエネルギー産 生などを介して、生命維持に寄与していることが 明らかになっている。

\section{3. 胎盤特異的オートファジー ノックアゥトマウスと PE 胎盤形成における役割}

我々は、胎盤におけるオートファジー機能の解 明を目指して、胎盤特異的 Atg7 欠損 (cKO) マ ウスを大阪大学吉森保教授、伊川正人教授らと の共同研究で作成した ${ }^{[3]}$ 。Atg7 遺伝子は、図 1 に示すようにオートフォゴソーム形成に関わる 2 経路を制御することが知られており、その久損に より胎盤におけるオートファジーが抑制されるこ とが分かった。そして、それら cKO 胎盤を移入 された偽妊娠マウスは、コントロール胎盤（EGFP を発現させている）に比し、その母獣は妊娠後期 に有意に血圧が上昇し、胎盤が有意に縮小するこ とが明らかとなった（図 2)。一方で、胎児重量 及び母獣からは蛋白尿の増加は認めなかった。ま た、オートファジーの基質である p62 蛋白をオー トファジー抑制マーカーとして免疫染色を行った ところ、マウス胎盤における Spongiotrophoblst 層およびGiant trophoblastにp62 が蓄積し、そ れらの部位がよりオートファジー抑制に晒されて いる可能性が示唆された。次に機能評価のため、 ヒト EVT 細胞のように、胎盤の最外層に存在す る Giant trophoblastの子宮側への浸潤を評価した ところ、浸潤細胞の低下および血管リモデリング 不全が観察された。これは、我々がヒトEVT 細 胞においてオートファジー欠損させた細胞でみら れた特徴と一致するものであり、PEの第一ステッ プである胎盤低形成に関連する胎盤病理学的特徵 でもあった ${ }^{[2]}$ 。また、胎盤低形成のメカニズムと して Labyrinth 層および Spongiotrophoblst 層に おいてアポトーシス細胞が増加し、その結果胎盤
低形成につながることが示唆された。最後に、分 子メカニズムを明らかにすべく、PE の第二ステッ プに関連する因子 (COMT、PIGF、sENG、sFlt1) の発現を cKO とコントロールで比較したが、抗 血管新生阻害因子および COMT には発現変化は 認めず、cKOにおいて PIGF の mRNA レベルが有 意に低下していた。これらのことから、胎盤にお けるオートファジー抑制は胎盤低形成に関与する

(A)

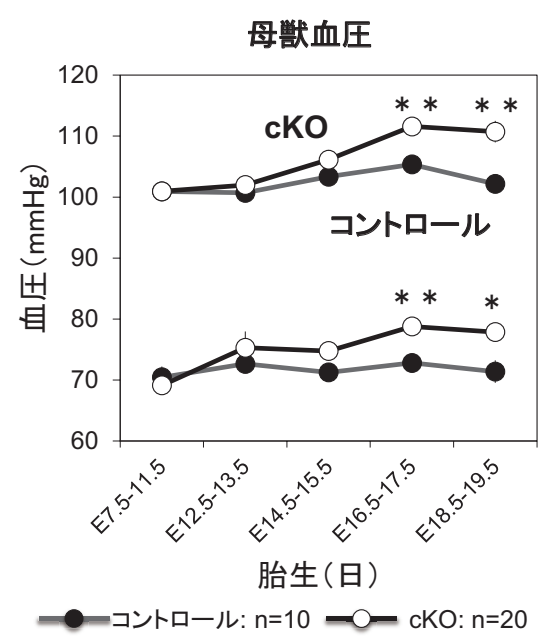

(B)

\section{胎盤重量}

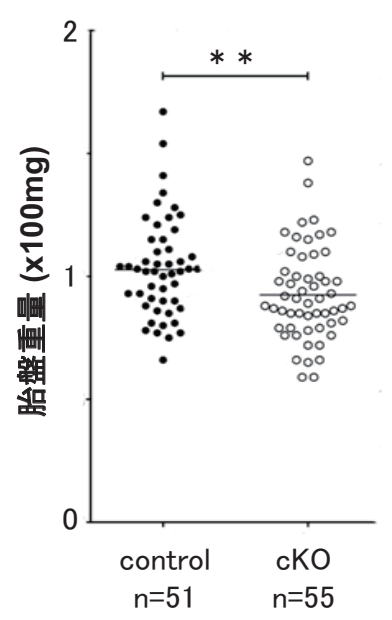

図 2. 胎盤特異的オートファジーノックアウトマウスの表現型 妊娠期間（胎生7.5〜19.5日）における母獣血圧（A） および 胎盤重量（B）を示す。

黒丸：コントロール

白丸：胎盤特異的オートファジーノックアウトマウス（cKO) $*: p<0.05 、 * *: p<0.01$ 。 
ことが示唆されるが、PEの第二ステップには直 接的関与が低いことが分かった（図 3 )。

\section{4.ヒトPE 胎盤にオートファジーの役割と 凝集蛋白蓄積のメカニズム（仮説）}

ここまで、我々はオートファジー抑制が PE 発 症に関わることを示した。一方で、他のグルー プからは PE 胎盤ではオートファジーが活性化し ているという報告もある ${ }^{[13,14]}$ 。そこで、我々は 胎盤特異的オートファジー欠損マウスを作成し、 オートファジー抑制が PE 発症の一因となり得る ことを示した。加えて、その後の検討により同マ ウス胎盤において凝集蛋白が蓄積していること を示唆するデータが得られている（論文投稿中 データ)。同様の現象は、これまでマウスを用い た神経細胞特異的 Atg5 欠損マウスの実験におい て証明されており、その結果、そのマウスは進行 性の運動障害を起こし、神経変性疾患モデルと なる ${ }^{[15]}$ 。さらに PE 患者の尿中および胎盤に凝 集蛋白が検出されることも分かっている ${ }^{[16,17]}$ 。 そして、凝集蛋白による毒性は、分裂細胞よりも 非分裂細胞により影響が出やすいと考えられてお り、細胞分裂が起こらないと、より多くの凝集蛋

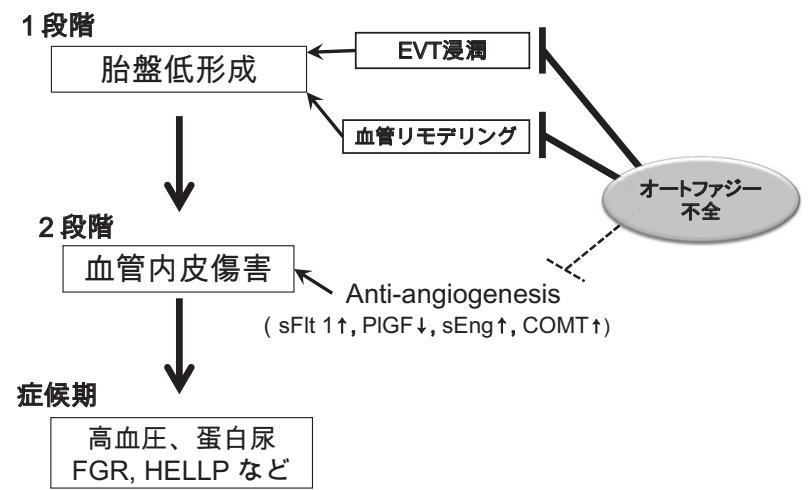

図 3. PE 発症 2 段階仮説におけるオートファジーの関与

$\mathrm{EVT}$ 浸潤不全および血管リモデリング不全が胎盤オートファジー 不全によって引き起こされる。その結果、胎盤は低形成となる (第一ステップ)。一方で、胎盤オートファジー不全は PIGF 以 外の血管新生関連因子には影響を与えないため、血管内皮傷害 (第二ステップ）への関与は少ないと予想される。
白が蓄積し細胞機能を抑制することになるのだろ う。そのため、これらの現象は胎盤形成が完成し た第 2 三半期以降に起こりやすいと、我々は推 測している。では、如何にしてヒトPE 胎盤にお いて凝集蛋白が蓄積するのか?そこには、オート ファジーの最終段階に関与するリソソーム数の減 少が関与している（投稿中データ）。オートファ ジーが最終段階で抑制された場合、細胞内のオー トファゴソームは増加するが、オートリソソーム は減少し、オートファジーは抑制された状態とな る（図 4)。これまでPE 胎盤やFGR 胎盤におけ るオートファゴソーム増加を示した論文は、そこ をミスリードした結果ではないないかと考えられ る。一方で、現在生体組織においてオートファジー 活性を正確に評価することができないため、我々 の仮説の証明には更なる検討が必要であることも 申し添えておく。

\section{5．PE 胎盤におけるオートファジー： 今後の展望}

PE（早発）重症例抢よび PE 軽症例は異な る病態であると認識されてきている。一方で、 Placenta-mediated pregnancy complications にお

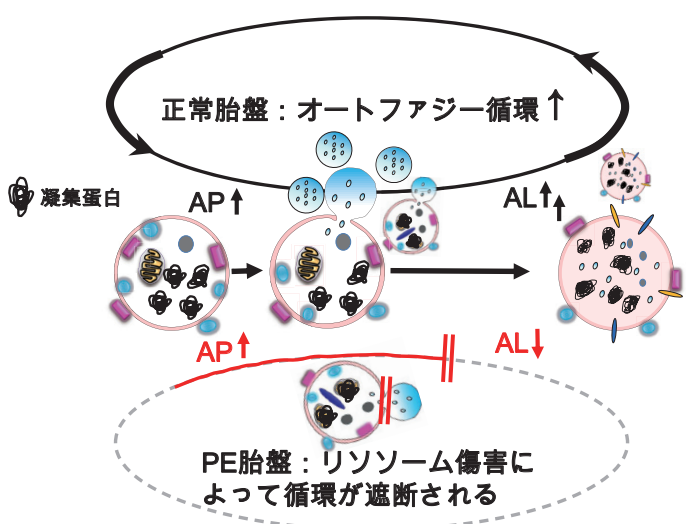

図 4.ヒトPE 胎盤におけるオートファジー抑制メカニズム（仮説） 正常胎盤においてオートファジーは正常に循環している。その ため、不要な凝集蛋白は蓄積しにくい。そのため、オートファ ゴソーム ( AP) およびオートリソソーム ( $\mathrm{AL}$ ) は増加する。一 方PE胎盤では、リソソームが減少することで $A P \rightarrow A L$ への移行 が制限されるため、AP が増えていても AL が増えない状況にな り、オートファジー循環は遮断（あるいは減速）された状態と なる。

Reproductive Immunology and Biology Volume 33 • Number 1 • November 2018 Japan Society for Immunology of Reproduction 
いて、共に胎盤低形成という共通性を持ちなが ら、PE 重症＋FGR 合併例と FGR 単独例（母体血 圧上昇なし）の病態の違いは明らかとなっていな い。今回の我々の検討からは、オートファジー不 全による胎盤低形成には、FGR を伴わなかった ことから、オートファジー不全は FGR 単独例に はあまり寄与していないのではないかと考えてお り、その病態の違いを解明すべく研究を進めてい る。現時点では、生体蔵器におけるオートファジー 活性を推測することは難しいが、今後そのような 技術が開発できれば、胎盤における薬剤を介した オートファジー活性を評価できるようになり、非 常に有益なツールになると考えている。そしてそ れは、PE 胎盤で低下したオートファジーを改善 する、新たな治療戦略になると考えられる。

\section{文 献}

1 ) J.M. Roberts, C.A. Hubel. 2009. The two stage model of preeclampsia: variations on the theme. Placenta. 30 Suppl A: S32-37

2) Nakashima A, Yamanaka-Tatematsu M, Fujita N, Koizumi K, Shima T, Yoshida T, Nikaido T, Okamoto A, Yoshimori T, Saito S. 2013. Impaired autophagy by soluble endoglin, under physiological hypoxia in early pregnant period, is involved in poor placentation in preeclampsia. Autophagy. 9:1-14.

3 ) Aoki A, Nakashima A, Kusabiraki T, Ono Y, Muto M, Kumasawa K, Yoshimori T, Ikawa M, Saito S. 2018. Trophoblast-specific conditional knockout mice develop gestational hypertension. Am J Pathol. (in press)

4 ) Venkatesha S, Toporsian M, Lam C, Hanai J, Mammoto T, Kim YM, Bdolah Y, Lim KH, Yuan HT, Libermann TA, Stillman IE, Roberts D, D'Amore PA, Epstein FH, Sellke FW, Romero R, Sukhatme VP, Letarte M, Karumanchi SA. 2006. Soluble endoglin contributes to the pathogenesis of preeclampsia. Nat Med. 12:642-649

5 ) Kumasawa K, Ikawa M, Kidoya H, Hasuwa H, Saito-Fujita T, Morioka Y, Takakura N, Kimura T, Okabe M. 2011. Pravastatin induces placental growth factor (PGF) and ameliorates preeclampsia in a mouse model. Proc. Natl.
Acad. Sci. U. S. A. 108:1451-5.

6 ) Levine RJ, Maynard SE, Qian C, Lim KH, England LJ, Yu KF, Schisterman EF, Thadhani R, Sachs BP, Epstein FH, Sibai BM, Sukhatme VP, Karumanchi SA. 2004. Circulating angiogenic factors and the risk of preeclampsia. N. Engl, J. Med. 350:672-683.

7 ) Thadhani R, Kisner T, Hagmann H, Bossung V, Noack S, Schaarschmidt W, Jank A, Kribs A, Cornely OA, Kreyssig C, Hemphill L, Rigby AC, Khedkar S, Lindner TH, Mallmann P, Stepan H, Karumanchi SA, Benzing T. 2011. Pilot study of extracorporeal removal of soluble fms-like tyrosine kinase 1 in preeclampsia. Circulation. 124:940-950.

8 ) Rolnik DL, Wright D, Poon LC, O'Gorman N, Syngelaki A, de Paco Matallana C, Akolekar R, Cicero S, Janga D, Singh M, Molina FS, Persico N, Jani JC, Plasencia W, Papaioannou G, Tenenbaum-Gavish K, Meiri H, Gizurarson S, Maclagan K, Nicolaides KH. 2017. Aspirin versus Placebo in Pregnancies at High Risk for Preterm Preeclampsia. N. Engl, J. Med. 377:613-622.

9）吉森保. 2009. 疾患に対抗するオートファ ジー。実験医学. 27:2918-2923.

10) Nakashima A, Aoki A, Kusabiraki T, Cheng SB, Sharma S, Saito S. 2017. Autophagy regulation in preeclampsia: Pros and cons. J Reprod Immunol. 123:17-23.

11) Gawriluk TR, Ko C, Hong X, Christenson LK, Rucker EB 3rd. 2014. Beclin-1 deficiency in the murine ovary results in the reduction of progesterone production to promote preterm labor. Proc. Natl. Acad. Sci. U. S. A. 111:E4194203

12) Tsukamoto S, Kuma A, Murakami M, Kishi $C$, Yamamoto A, Mizushima N. 2008. Autophagy is essential for preimplantation development of mouse embryos. Science 321:117-120.

13) Kalkat M, Garcia J, Ebrahimi J, Melland-Smith M, Todros T, Post M, Caniggia I. 2013. Placental autophagy regulation by the BOKMCL1 rheostat. Autophagy. 9:2140-2153.

14) Akaishi R, Yamada T, Nakabayashi K, Nishihara H, Furuta I, Kojima T, Morikawa M, Yamada T, Fujita N, Minakami H. 2014. Autophagy in the 
placenta of women with hypertensive disorders in pregnancy. Placenta. 35:974-80.

15) Hara $T$, Nakamura $K$, Matsui $M$, Yamamoto A, Nakahara Y, Suzuki-Migishima R, Yokoyama M, Mishima K, Saito I, Okano H, Mizushima N. 2006. Suppression of basal autophagy in neural cells causes neurodegenerative disease in mice. Nature. 441:885-889.

16) Kalkunte SS, Neubeck S, Norris WE, Cheng SB, Kostadinov S, Vu Hoang D, Ahmed A, von Eggeling F, Shaikh Z, Padbury J, Berg
G, Olofsson A, Markert UR, Sharma S. 2013. Transthyretin is dysregulated in preeclampsia, and its native form prevents the onset of disease in a preclinical mouse model. Am J Pathol. 183:1425-1436.

17) Buhimschi IA, Nayeri UA, Zhao G, Shook LL, Pensalfini A, Funai EF, Bernstein IM, Glabe CG, Buhimschi CS. 2014. Protein misfolding, congophilia, oligomerization, and defective amyloid processing in preeclampsia. Sci. Transl. Med. 6:245ra92. 


\title{
The role of autophagy for protein aggregation in preeclampsia
}

\author{
Akitoshi Nakashima a) ,Tae Kusabiraki a) ${ }^{\text {, Aiko Aoki a) }}$, Tomoko Shima a) , Azusa Sameshima a), \\ Satoshi Yoneda a), Shi-Bin Cheng ${ }^{\text {b) }}$, Osamu Yoshino a), Masahito lkawa c), Tamotsu Yoshimori d), \\ Surendra Sharma ${ }^{\text {b) }}$, Shigeru Saito ${ }^{\text {a) }}$ \\ a) Department of Obstetrics and Gynecology, Faculty of Medicine, University of Toyama \\ (Sugitani 2630, Toyama, 930-0194, Japan) \\ b) Department of Pediatrics, Women \& Infants hospital, Brown University \\ (Providence, RI, USA) \\ c) Research Institute for Microbial Diseases, Osaka University \\ (3-1 Yamadaoka, Suita, Osaka, 565-0871, Japan) \\ d) Department of Genetics, Graduate School of Medicine, Osaka University \\ (2-2 Yamadaoka, Suita, Osaka, 565-0871, Japan) \\ Corresponding: Akitoshi Nakashima \\ Department of Obstetrics and Gynecology, Faculty of Medicine, University of Toyama \\ Sugitani 2630, Toyama, 930-0194, Japan \\ Tel: $+81-76-434-7357$ \\ Fax: $+81-76-434-7357$ \\ E-mail:akinaka@med.u-toyama.ac.jp
}

Key words:

Autophagy, neurodegenerative diseases, extravillous trophoblasts, preeclampsia, protein aggregation

\begin{abstract}
:
Preeclampsia is one of the placenta-mediated pregnancy complications, which includes fetal growth restriction (FGR), late pregnancy loss, or placental abruption. Severe pregnancy complications are related with abnormalities of placentas. In preeclampsia, two stage disorder theory has been proposed for the pathophysiology of preeclampsia: poor placentation is occurred at the first step followed with the systemic endothelial dysfunction at the second step. We, so far, have been focused on the role of autophagy for placentation to clarify the mechanism of development of preeclampsia. The inhibition of autophagy was mediated with the failure of functions, invasion and vascular remodeling, in extravillous trophoblasts (EVTs). In addition, placenta-specific atg7 knockout mice, in which autophagy was impaired in trophoblasts, showed growth restriction in placentas and high blood pressure in dams. On the other hand, neither proteinuria in dams nor FGR were seen in the mice. Taken together, impairment of autophagy was mainly mediated with the first step, but not the second step. Recently, we obtained some new findings related with the protein aggregation by autophagy inhibition, as can be seen in neurodegenerative diseases. In this paper, we review the role of autophagy in preeclampsia.
\end{abstract}

